\title{
A Teologia da Libertação e as mulheres
}

\author{
La Teología de la Liberación y las mujeres
}

\section{Liberation Theology and Women}

\author{
iD Ivone Gebara \\ Universidade Católica de Louvain, Louvain, Bélgica. \\ ivonegebara@gmail.com
}

Resumo: O presente texto recupera aspectos da história e conceitos da Teologia da Libertação em relação às mulheres. Mostra que, apesar dos avanços significativos dessa teologia para refletir a respeito dos pobres da América Latina, como teologia ela seguiu encarcerada na instituição católica, repetindo à sua maneira a mesma tradição ocidental formulada no Credo de Nicéia. As teólogas, abordando a problemática específica das mulheres e questionando o atrelamento da dogmática a conceitos patriarcais excludentes, não encontraram boa acolhida no libertário mundo masculino. Esforços louváveis são reconhecidos, porém considerados insuficientes para transformar velhos conteúdos e velhos poderes. O texto reflete alguns desafios feitos à Teologia da Libertação a partir da introdução da sexualidade como mediação antropológica fundamental e mostra os limites das mediações econômicas e sociais que a Teologia da Libertação priorizou. Em meio ao desenvolvimento dessas questões, delineiam-se alguns caminhos propostos pelas teologias feministas que se desenvolveram fora das instituições clericais e que seguem seu caminho atual com inevitáveis dificuldades.

Palavras-chave: Libertação. Feminismo. Sexualidades. Teologias. Igreja.

Resumen: Este texto recupera aspectos de la historia y conceptos de la Teología de la Liberación en relación con las mujeres. Muestra que, a pesar de los avances significativos de esa teología para reflexionar a partir de los pobres de Latinoamérica, como teología sigo encarcelada en la 
institución católica repitiendo a su manera la misma tradición occidental formulada en Nicea. Las teólogas abordando la problemática específica de las mujeres y cuestionando el entrelazamiento de la dogmática con lo conceptos patriarcales excluyentes no encuentran buena acogida en el libertario mundo masculino. Grandes esfuerzos son reconocidos, pero son insuficientes para trasformar viejos contenidos y viejos poderes. El texto refiere algunos desafíos hechos a la Teología de la Liberación a partir de la introducción de la sexualidad como mediación antropológica fundamental y muestra los limites de las mediaciones económicas y sociales que la Teología de la Liberación priorizó. En medio al desarrollo de esas cuestiones, delinea algunos caminos propuestos por las teologías feministas que se desarrollaron fuera de las instituciones clericales y que siguen su camino actual con inevitables dificultades.

Palabras-clave: Liberación. Feminismo. Sexualidades. Teologías. Iglesia.

Abstract: The present text recovers aspects of the history and concepts from Liberation Theology in relation to women. It shows that despite significant advances of this theology to reflect from the perspective of the poor in Latin America, as a theology it continues imprisoned in the Catholic institution repeating in its own way the Western tradition formulated in the Nicean Creed. Theologians addressing the specific problematic of women and questioning the coupling of dogma with excluding patriarchal concepts do not find a warm welcome in the liberated male world. Honorable attempts are recognized, however considered insufficient to transform the old content and old powers. The text reflects some challenges to Liberation Theology from the introduction of sexuality as fundamental anthropological mediation and shows the limits of economic and social mediations which Liberation Theology prioritized. In the midst of developing these questions, it outlines some of the ways proposed by feminist theologians that are developed outside of the clerical institutions and which follow their own path with inevitable difficulties.

Keywords: Liberation. Feminism. Sexuality. Theology. Church.

Data de recebimento: 30/06/2019

Data de aceite: 09/09/2019 


\section{Introdução}

Escrevo este texto em tempos obscuros para os processos de "libertação" na América Latina. O passado recente e suas conquistas em diferentes setores da atividade e do pensamento humanos vêm sendo, até certo ponto, varridos da história presente por ventos contrários que sopram de muitos lugares. Velhas e novas interpretações emergem como se quisessem ocultar acontecimentos e fatos passados, antes historicamente comprovados, como se este comportamento fosse uma força para as novas/velhas ideologias que se afirmam. Negam-se as ditaduras, as torturas do passado, os genocídios, os regimes de exceção, a censura, a breve libertação, a evolução da ética e do direito. Uma nova organização chamada de "ordem", "progresso", "anticorrupção" e "respeito à família" tenta impor-se como se os seus autores fossem os novos arautos da moralidade dos Estados e das Igrejas. Não só os esforços de muitos grupos ativistas políticos e religiosos do passado, mas os movimentos feministas mais recentes que atuam nos movimentos sociais e eclesiais vêm sendo criminalizados pelos novos detentores do poder político, econômico, cultural e religioso. Inspirados pela ordem e pelo desenvolvimento exigido pelas novas formas do capitalismo financeiro vigente, eles atuam em diferentes meios fazendo acreditar que sua mensagem corresponde a mais pura vontade divina. Seus discursos políticos são apoiados por argumentos religiosos e a figura do Deus invisível "todo poderoso" aparece como fundamento de suas ações.

Essa situação contextualiza também a reflexão sobre a história das mulheres no passado da Teologia da Libertação e no presente dos poucos espaços onde as teologias feministas ${ }^{1}$ ainda podem discretamente frutificar e se expressar. Esses espaços correspondem a iniciativas de contestação, de construção de sentidos e de resistência, sobretudo fora dos muros das igrejas. É por meio de um resgate diferente da tradição cristã, ainda fortemente presente nas culturas do continente, que tentam argumentar e dialogar

\footnotetext{
1 A expressão "teologia feminista" se impôs na década de 1970 através do trabalho de muitas autoras que tentaram denunciar a opressão religiosa das mulheres a partir da figura de Deus Pai plasmada no poder religioso das figuras masculinas. $\mathrm{O}$ livro de Mary Daly (1973) é considerado um clássico nessa temática.
} 
com a diversidade propondo algumas saídas para o imediato das muitas dores.

O resgate diferenciado da tradição cristã nas teologias feministas se faz por caminhos éticos e revela a convergência entre muitas outras tradições éticas e religiosas que se miscigenaram no continente latino-americano. Essa miscigenação religiosa me parece apontar para uma crise não apenas da Teologia da Libertação, mas da própria teologia como "ciência de Deus" nos moldes de um pensamento metafísico. Sem dúvida, aqui, o corte entre ricos e pobres, entre classes sociais, etnias, orientações sexuais e fronteiras religiosas é vivido de formas diferentes. Há uma mistura visível que se faz sentir, como se a vida atual tentasse negar as antigas classificações científicas reforçadas pelos diferentes aparatos teóricos. Entretanto, o cristianismo fixista tenta impor-se buscando, através da direita política, reafirmar suas convicções e fundar suas ações.

Para muitas/os a formulação teológica metafísica da fé, apesar de sua predominância, não dá mais conta dos novos discursos da ciência, do pluralismo populacional e nem das reivindicações feministas. Na mesma linha, as fórmulas teológicas libertárias parecem estreitas demais e clericais demais para inspirar e acolher as novidades que emergem. Questões sobre identidades sexuais, direitos das mulheres como parte dos direitos humanos, pertenças religiosas institucionais híbridas, ecologias entre muitas outras questões exigem outros instrumentos de análise e outras teologias.

Hoje, novas intervenções sociais, políticas e culturais afetam o cristianismo e suas múltiplas expressões. Lideranças religiosas se infiltram na política e lideranças políticas buscam alianças religiosas como formas de manutenção ou de ruptura com a velha ordem da distinção dos dois poderes: o espiritual e o material. 0 ambiente de insegurança e polarização é notável. Além disso, há uma espécie de anarquismo prático que se infiltra em diferentes meios que vão dizendo "não" às antigas roupagens da ordem e da libertação. Algo diferente; uma potência criativa do "não" à 
A Teologia da Libertação e as mulheres Ivone Gebara

ordem dada se desenha através de muitos grupos que seguem um caminho cuja escrita original é ainda pouco decifrável.

Desde o início dos anos 1980, no interior das teologias latino-americanas um mal-estar provocado pelas reivindicações feministas incipientes provoca sutis reações de desestabilização na suposta harmonia teológica falocêntrica². As teologias feministas incomodavam e provocavam as emoções patriarcais de muitos dos fiéis adeptos da libertação. Entretanto, hoje a Teologia da Libertação se tornou mais objeto de teses de doutorado ou de mestrado, de artigos de revistas de cultura e de história, e menos um pensamento performático que dá conta da complexa realidade dos marginalizados/as da América latina ${ }^{3}$. Não há novos projetos políticos e as esperanças históricas de uma justiça social distributiva encontram-se enfraquecidas.

É nesse complexo ambiente que tentarei delinear aspectos desse processo teológico, sobretudo como testemunha de quem viveu nos encantadores átrios nacionais e internacionais dos que se consideravam "a voz dos sem voz". E vivi tudo isso ainda jovem, muitas vezes sendo perguntada sobre as razões de minha presença nesse meio masculino sagrado e erudito. Poucos sabiam que as agências financiadoras de fundos na época exigiam uma presença mínima de mulheres para liberar o dinheiro necessário para as assembleias nacionais e internacionais da Teologia da Libertação e, por razões econômicas, os teólogos tiveram que acolher em seu meio a presença de algumas "incômodas filhas de Eva".

Escrevo, desde os limites do presente sobre águas passadas, porém ainda perceptíveis nas posturas clericais de jovens e velhos de hoje. A hegemonia teológica masculina não acolherá o novo lugar das mulheres sem a gradativa transformação dos fundamentos que sustentam a chamada fé cristã e sem uma contínua educação pessoal e coletiva.

\footnotetext{
2 A expressão harmonia teológica falocêntrica tem a ver com a dominação masculina centrada simbolicamente no falo (sexo), que pretende de forma equivocada organizar o mundo de forma ordenada e harmoniosa em oposição às mulheres que introduzem a desarmonia e a quebra da ordem masculina.

30 volume 78, n. 311, Set./Dez. 2018 da REB (Revista Eclesiástica de Teologia) publicada pela Faculdade de Teologia de Petrópolis, por exemplo, contém alguns estudos de referência à Teologia da Libertação como possível processo de renovação eclesial na América Latina.
} 
Hoje, o medo e a imposição da ordem tradicional reaparecem para inibir qualquer movimento que arranque o poder religioso que a teologia metafísica legitima na ordem religiosa, política e social estabelecida. Nessa linha, o feminismo realizou e realiza uma intervenção política e filosófica extremamente original no Cristianismo e ela tem suas origens no movimento feminista internacional mais amplo, e, em parte, também na Teologia da Libertação, referência importante para muitas de nós. A busca de libertação abriu para nós mulheres teólogas horizontes inesperados e imprevisíveis. Não era apenas a libertação dos pobres como diziam os teólogos da libertação. Era a libertação de nossas identidades sexuais, de nossas relações cotidianas e a libertação da opressão social, política e religiosa imposta ao nosso sexo pela "natureza patriarcal". Convocamos e acolhemos os saberes de nossos corpos; desconstruímos narrativas; desmanchamos velhos preceitos e preconceitos; criticamos os absolutos; relemos a história bíblica e a história dos cristianismos buscando os traços de nossa presença escondida, de nossa voz silenciada e de nossos direitos negados. Tentamos resgatar nossas sexualidades, para além dos moralismos e dos controles ditados pelos representantes do poder divino. Confundimos e nos confundimos e sobrevivemos à avalanche de agressões dos que julgam que tudo tem que ser segundo o espelho do narcisismo falocrático imposto como 'vontade divina'. Resistimos para não sermos seus "bodes expiatórios" e nem nova massa de manobra de seus desejos de dominação. Apesar do medo, a novidade continua irrompendo através de pequenos veios que saem como reações ao caudaloso rio da ordem estabelecida pelo capitalismo hodierno, que odeia o pensamento e a ação revolucionária das mulheres. Essa é uma brevíssima pincelada do contexto deste texto.

\section{O silenciamento das mulheres como parte da Teologia}

Gustavo Gutierrez, numa espécie de pré-introdução ao seu livro Teologia da Libertação, reproduz um texto do escritor José 
A Teologia da Libertação e as mulheres

Maria Arguedas tirado da obra Todas las sangres. Nela, um sacerdote espanhol pedia ao sacristão mestiço para responder à missa cantando em latim. Inseguro, o homem se recusa e responde: "Como voy a cantar? La Gertrudis igual que angel canta". O padre responde: "La Gertrudis no piensa en Dios; canta triste, si, porque es deforme". E o mestiço sacristão contesta:

\begin{abstract}
Padrecito, tu no entiendes el alma de indios. La Gertrudis aunque no conociendo Dios, de Dios es? Quien, si no (El), le dio esa voz que limpia el pecado? Consuela al triste, hace pensar al alegre, quita de la sangre cualquier suciedad?

- Bueno terco, no puedo obligarte. Esa 'Kurku' tiene algo, algo extraño, duele.

- El Dios, pues, padrecito. Ella ha sufrido entre los señores. El Dios de los señores no es igual. Hace sufrir sin consuelo (GUTIERREZ, 1971, p. 6).
\end{abstract}

O canto diferente de Gertrudes, seu sofrimento pessoal que dói através de sua voz, seguiu não sendo ouvido como apelo à teologia pela maioria dos teólogos da libertação de ontem e os remanescentes de hoje. O Deus das teologias da ordem ou da libertação continua fazendo as mulheres sofrerem sem consolo, penalizando e ocultando seus corpos e suas vozes. Este é o ponto central dessa reflexão que, embora querendo posicionar-se além do modelo de conflitos e debates que a Teologia da Libertação indiretamente fez com a teologia europeia da época, não fugirá sem dúvida à polêmica e aos compreensíveis desacordos ${ }^{4}$. Neste texto não será feita uma análise feminista ingênua em relação a uma produção teológica tão importante, sobretudo para a América Latina. Não se negará a intencionalidade social das teologias da libertação preocupadas com a opressão e libertação dos pobres. Mas, sim, uma consideração de caráter epistemológico, emocional e cultural que convida a refletir sobre o que impediu e ainda impede de se escutar um canto saído de corpos diferentes, sem representação de

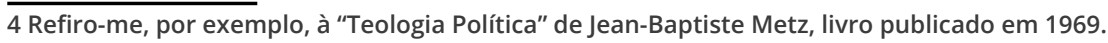


poder social e eclesial reconhecidos. Mesmo se na Introdução de sua Teologia da Libertação, Gustavo Gutierrez inclui a referência ao Evangelho como "experiência de homens e mulheres" (GUTIERREZ, 1971, p. 9), em sua reflexão corrente há na realidade uma questão básica que é a de saber a que homens e a que mulheres ele se dirige e quais são seus reais problemas. As críticas que Gutierrez fez a outras teologias podem ser usadas para comprovar os limites de qualquer reflexão humana sobre o mundo, inclusive a da Teologia da Libertação e da Teologia Feminista da Libertação. Em outros termos, não se trata apenas de precisar os destinatários de seu texto, mas de abrir a reflexão para problemáticas específicas que os destinatários estão vivendo. Não se trata apenas de dar respostas teóricas aos que as podem entender, mas articular modos de conhecimento diferentes, a partir de experiências vitais diferentes, para transformar doutrinas seculares em vista de sujeitos concretos.

Sem dúvida, as análises teóricas não conseguem brindar as individualidades em seus diferentes aspectos, mas no caso das mulheres não são apenas individualidades, trata-se de metade da humanidade e metade da América Latina cuja voz não foi levada em consideração de forma especial nas igrejas. A alegação de inclusão no mundo masculino é pura falácia na medida em que o discurso universalista pretende incluir a todos idealmente, porém acaba excluindo muitas do exercício real da cidadania eclesial. Além disso, embora o foco da Teologia da Libertação seja o pobre, percebemos na leitura dos seus textos que os destinatários da Teologia da Libertação parecem ser pessoas universitárias ou de boa formação teológica para serem capazes de entender as mudanças teológicas pleiteadas, as mediações sociais e hermenêuticas bíblicas, assim como as referências a diversos autores. De fato este procedimento é compreensível no universo das teorias, porém a teologia sempre quis ser mais do que uma teoria.

A busca feita pelos pobres por uma religião de apoio aos seus sofrimentos e as dores imediatas dos corpos na sua cotidianidade não encontram alívio prático nas teorias libertárias. 
A Teologia da Libertação e as mulheres Ivone Gebara

Ao afirmar isso, não estou de forma alguma fazendo uma crítica geral à Teologia da Libertação, mas mostrando que ela sofre de insuficiências semelhantes àquelas que ela denunciou nos textos de seus opositores europeus. Certamente a reflexão teológica da libertação inclui como preocupação o indígena mestiço e a pobre cantora Gertrudes, mas o mundo deles é distinto do mundo da teologia. Sua linguagem é distinta, suas análises do mundo são outras, a expressão de sua fé é outra. Temos pouco acesso a esse mundo a partir de nossos conceitos filosóficos e teológicos ocidentais. Nossos corpos e emoções foram moldados com base em outras realidades. Nossos conceitos são distantes de suas vidas e por isso a dúvida sobre nossas interpretações deve nos habitar.

O mundo da oficialidade teológica, mesmo a libertária, fala outra linguagem e propõe caminhos muitas vezes inacessíveis aos que de fato necessitam libertar-se das estruturas do poder dominante e equilibrar-se no duro labor de buscar saúde e o pão cotidiano para si e sua prole. Além disso, trata-se de uma produção teórica intelectual clerical, mesmo quando não seja feita necessariamente por clérigos. O esquema clerical patriarcal, ou seja, o esquema a partir do qual o clero ou os teóricos clérigos e seus leigos definem os conteúdos a serem acreditados, é o pano de fundo e uma constante na vida da Igreja católica. O papel das comunidades é bastante minimizado, visto que tudo deve passar pelo crivo dogmático identificado à fé. Incluem-se os pobres na teoria sobre eles, mas pouco aparece a cosmovisão dos muitos pobres. Reconheço a dificuldade que os teóricos têm, mas nem por isso posso deixar de assinalá-la. O próprio conceito de fé é limitado a crenças que nem sempre têm a ver com o cotidiano da vida dos pobres. Afirmam-se abstrações proclamadas em séculos passados e não se perguntam por sua vigência no século XXI, na vida dos que a reproduzem sem pensá-las. Por exemplo, em algumas celebrações se articulam nas homilias problemas da comunidade e em seguida se reza o Credo de Nicéia ${ }^{5}$. E o povo reza sem conexão com o conteúdo.

$\overline{50}$ Credo de Nicéia é a reafirmação sintética das crenças dogmáticas do Cristianismo promulgadas pelo Concílio de Nicéia (325) convocado pelo Imperador Constantino preocupado com o nascimento de heresias em seu Império. Até hoje nas Missas cristãs esse Credo é repetido pelos fiéis. Nicéia é uma cidade próxima à Constantinopla. 
A Teologia da Libertação e as mulheres

Muitas vezes não nos damos conta que o mundo cristão é um pluralismo de mundos e de experiências. As teologias nada mais são do que a explicitação do pensamento de outro pequeno mundo, o mundo acadêmico que sem perder seu valor não dá conta de entender todos os mundos. $\mathrm{O}$ advento das teologias feministas da libertação, com seu diálogo intercultural, tenta manifestar algo dessa realidade diferente e ensaiar reflexões inclusivas com imensas dificuldades.

\section{A presença das mulheres na Teologia da Libertação: um pouco de história}

A narrativa que segue vem marcada por uma dimensão testemunhal. É, portanto, limitada, incompleta e pode ser contestada ou explicitada a partir de outras opiniões e escrituras.

Fiz parte do movimento teológico libertário na América Latina. Participei de muitos encontros nacionais e internacionais, embora desde o secundário lugar de mulher. Estudei vários autores e dei aulas de filosofia e teologia na linha da libertação por muitos anos, sobretudo no Instituto de Teologia do Recife, marcado pela figura extraordinária de Dom Helder Câmara. Participei junto a outros/as da redação da coleção "Teologia e Libertação", projeto que pretendeu reescrever a teologia a partir dos pobres e daquele momento da América Latina e do mundo. Com a teóloga Maria Clara Bingemer publicamos o livro Maria Mãe de Deus e Mãe dos Pobres, no qual ensaiamos uma Mariologia com base no conceito de libertação e da valorização das mulheres no Cristianismo. Meu percurso, em seguida, foi entrando na linha do feminismo crítico. Percebi o quanto fazer teologia como mulher e fazer teologia como mulher feminista era diferente. No primeiro modelo, devia aprender e reproduzir as teologias masculinas e receber as glórias de boa teóloga que outorgavam. No segundo, precisava introduzir-me na crítica ao mundo patriarcal e suas teorias religiosas 
de manutenção da submissão das mulheres a seus poderes. As novas mediações analíticas, embora conservassem as análises de classe, eram diferentes e saíam da ortodoxia teológica libertária. Esta opção valeu-me inúmeras críticas e silenciamento por parte da hierarquia católica romana.

Hoje, como outras pessoas, vivo uma perplexidade diante da lentidão das mudanças dos conteúdos dogmáticos mantidos pelas instituições cristãs. Os discursos de abertura ao mundo e aos seus grandes desafios parecem limitados quando se trata de mudar a dogmática identificada à própria fé cristã. Há muitos discursos, mas os pontos centrais da formulação da fé, aqueles que excluem as mulheres e outros "pecadores" de uma inclusão real não são tocados. A dogmática oficial considerada parte da revelação divina não pode ser modificada. Aqui se encontra um lugar de conflitos, sobretudo com a hierarquia católica mantenedora da tradição patriarcal.

Tem sido uma preocupação central em minha reflexão a tentativa de deslocar a metafísica teológica para uma ética teológica. A busca de uma transcendência ética, vivida nas relações cotidianas, se ajusta mais às buscas contemporâneas das mulheres do que a obediência a uma ordem transcendental vertical e masculina estabelecida em tempos passados. As palavras "teológica" e "teologia" têm nessa nova perspectiva uma significação abrangente, que toca o universo dos sentidos e não necessariamente a figura de um Deus, Ser em si mesmo ordenando o universo e julgando os seres humanos. Trata-se de uma postura marcada pelas filosofias contemporâneas que encontra os anseios libertários das mulheres numa "topia" cotidiana de renovadas libertações.

A violência que antes criticávamos apenas a partir da economia e da política, reaparece hoje em outras modalidades com a grande banalização da vida humana e da vida do planeta. Expande-se igualmente como violência crescente contra os corpos femininos e de muitas formas é corroborada pela sutil violência simbólica presente nas igrejas. É, pois, a partir dessas dores concretas especialmente das mulheres na sua diversidade social e cultural que os 
feminismos e a teologias feministas têm dado respostas que, com frequência, não se coadunam com as posturas morais das igrejas cristãs. As respostas fundamentam-se na crença na capacidade dos seres humanos de sentirem e agirem em favor dos outros, capacidade que evolucionou e tem evolucionado desde a irrupção dos seres humanos.

Vale lembrar, de forma breve, a quantidade crescente de cristianismos e de catolicismos em oposição entre si, dentro do que chamamos cristianismo e catolicismo (RESS, 2018). Estes convergem para a acentuação da diferença naturalizada e fixada entre mulheres e homens, diferença segundo seus adeptos querida por Deus. Nesse meio também se excluem as mulheres de seus direitos de cidadania. Uma colcha de retalhos diversificados e mal costurados parece crescer e muitas vezes não nos permite perceber se há um fio comum que as une.

Esse contexto instável e complexo evoluindo desde os tempos da teologia da libertação tem nos tornado críticas em relação à cegueira teórica e prática das igrejas e teologias masculinas, como se elas existissem acima das culturas ou emanassem da vontade divina a eles revelada. Basta que nos lembremos do quanto os projetos libertários como expressões do "Reino de Deus", da continuidade da caminhada do "Povo de Deus", da busca da "Terra prometida" através do estabelecimento de uma nova ordem social mundial foram, de certa forma, fundados na "promessa" do Deus libertador do seu povo. Promessa como garantia de libertação, assim como o povo hebreu foi libertado do jugo do faraó no Egito e crescerá como as areias do deserto. Nessa promessa as mulheres não tinham nada de especial. Entravam como parte do povo, de certa forma anônimas ou coadjuvantes de uma história de outros. Pode-se ainda hoje falar de "promessa"? Qual seria ela?

Nessa linha, a luta contra os projetos desenvolvimentistas do capitalismo internacional encontraram na teologia da libertação um fundamento revelado por Deus, quase uma "promessa" que seria cumprida, uma fé numa Palavra amorosa e justa que transformaria o mundo. Essa "promessa" nos obrigava a aceitá-la como 
parte integrante de nossa fé e a luta pela justiça nas suas diferentes formas era parte da ordem libertária divina em curso. Muitas mulheres sentiram-se obrigadas a aderir a ela, mesmo sem de fato acreditarem nessas ordens divinas, mas naquele momento esse era o caminho e essa era a ordem. O Deus amante dos pobres, seu libertador, seu justiceiro, pouco olhava para as mulheres e suas formas particulares de sofrimento. Estupradas, exploradas no trabalho, violentadas, prostituídas, empobrecidas pelas guerras, não se sentiam dignas desse Deus amante. Da mesma forma, as teólogas que se iniciavam nas lutas feministas não sentiam apoio por parte dos teólogos. Elas eram partidárias da vida das miseráveis sofredoras que mal entendiam o que eram estruturas de dominação, mas sabiam bem que seus esposos libertários eram ferozes dominadores dentro de suas casas, sabiam bem que eram elas que iam buscá-los nas portas dos bares e das prisões, além de terem que cuidar sozinhas de suas famílias.

O Deus dos pobres e da libertação não gostava das mulheres que faziam aborto, não gostava das que denunciavam a violência masculina, não gostava das sexualidades diferentes, do cheiro das menstruações, das dores do parto, dos anticoncepcionais, dos preservativos, da educação sexual para os homens. Essa guerra feminina era impura demais para ele, pois sendo Puro Espírito não podia ocupar-se com as baixezas da carne humana.

A cumplicidade e a validação recíproca entre o Deus libertador e os libertários que teorizavam sobre ele era grande demais. Estavam certamente na mesma luta, embriagados por sua própria eloquência e pela certeza das promessas divinas que pareciam avançar com a irrupção de novas lideranças.

Quantas mulheres sentiram o quanto o "seu deus" era diferente! Era pequeno demais para ser proclamado, era íntimo demais para ser publicado. Temiam falar dele diante da magnitude do Libertador. Melhor era calar e fazer de conta que estávamos no mesmo jogo de liberdades e ilusões. 
Passados anos desses acontecimentos, alguns sentimentos e reflexões emergem para fazer um contraponto ao que se viveu. E eles valem como alertas para não cairmos na tentação dos discursos absolutos mesmo se cheios de boas intenções; ternura, libertação e compaixão. As igrejas e as teologias, muito mais do que a sociedade civil, tiveram muita dificuldade em aceitar a "maioridade" religiosa das mulheres, em acolher a saída delas dos lugares que antes Ihes eram atribuídos, de acolher sua capacidade de pensar o mundo de forma em parte semelhante e em parte diferente da tradição patriarcal cristã. Nessa perspectiva, assinalo cinco tensões ou dificuldades como forma de ilustrar minha hipótese e reflexão acerca das passadas e atuais dificuldades da Teologia da Libertação de articular propostas performativas que acolham o pensamento feminista a partir da fé cristã.

\section{A tensão com a sexualidade humana}

Falar de tensão com a sexualidade humana parece uma decorrência lógica do que foi exposto acima. Entretanto, é bom lembrar que a sexualidade sempre foi um campo de batalha dentro do cristianismo masculino temeroso dos corpos materiais e devoto dos corpos espirituais. Corpos dedicados a Deus, controlando outros e propondo-Ihes caminhos de perfeição ou caminhos de contenção e prudência contra os arroubos das paixões carnais muitas vezes simbolizadas pelas mulheres. Nessa linha, o ascetismo foi um tema valorizado e destacado no cristianismo, visto que propunha a renúncia da atividade sexual através do celibato livremente assumido como via de perfeição. A pureza querida por Deus exigia a renúncia a responder ao desejo sexual. Para as mulheres que assumiam esse caminho, muitas vezes obrigadas a fazê-lo, se aconselhava a pureza perpétua através da manutenção de sua virgindade. Esse conselho continha resquícios de ensinamentos sobre as mulheres como mais sujeitas às tentações do demônio e aos desejos libidinosos. 
O século XX assiste e insiste numa mudança de compreensão da sexualidade, sobretudo na linha dos estudos psicanalíticos, e vai preparando novas compreensões e vivências da sexualidade masculina e feminina. Com o feminismo se dá uma revolução em relação à sexualidade feminina, acolitada por muitas descobertas científicas sobre as possibilidades de limitação da natalidade através dos anticoncepcionais.

A percepção de que, em grande parte, o sexo feminino se torna também objeto de consumo e de Mercado foi capital para a revolução feminista. Os processos de apropriação do próprio corpo e da própria história começaram a se fazer sentir cada vez mais nos movimentos de mulheres e, sem dúvida, os donos religiosos dos corpos femininos foram um alvo de ataque importante para nossas lutas. Em nome de Deus Pai afirmavam a posse de nosso corpo, impedindo-nos de escolher ou decidir sobre ele, indicando-nos o número de filhos que deveríamos ter, os prazeres permitidos e os proibidos, os deveres e obrigações em relação ao serviço aos homens, sempre nas formas e tempos aprovados por eles. Por isso, podemos dizer que as mulheres eram os sujeitos mais interessados na revolução sexual, uma vez que eram as maiores vítimas do sistema patriarcal repressivo.

Apesar disso, a sexualidade foi tema periférico na teologia da libertação. Não parecia ser importante para a libertação social e política e para as grandes causas sociais da América Latina da época. Ao falar dos pobres, se limitava sua pobreza à dimensão econômica e não às relações sociais e interpessoais em que a vivência da sexualidade era fundamental. Apesar de ser tema periférico, temos que lembrar que Enrique Dussel (1977) o trabalhou e, a partir dele, levantou algumas questões importantes à luz da libertação. Entretanto, tal contribuição não invalida a reflexão crítica sobre essa realidade.

Levantar a questão da tensão com a sexualidade humana na teologia da libertação significa não apenas introduzir questões feministas, mas mostrar por meio dela as diferentes formas de subordinação dos corpos que um sistema religioso patriarcal rea- 
lizou. Apesar da importância do feminismo, quero ir mais longe e apresentar a vivência política da sexualidade como um dos desafios maiores de hoje nas relações humanas, desafio que não teve e não tem espaço na estrutura e na epistemologia do pensamento da teologia da libertação.

As mediações da teologia da libertação para conhecer a realidade histórica do mundo foram mais centradas na sociologia e na ciência política. O passo das novas mediações de compreensão da vida introduz, em consequência, outras variações. Nosso sistema cognitivo tem conteúdos mais amplos que a teologia da libertação, entre outros, não conseguiu perceber. Neles é preciso falar da presença da sexualidade nos processos cognitivos, interpretativos e decisórios. Aqui, incluo igualmente o conhecimento da teologia e de sua hermenêutica própria. Se um tipo de pensamento é realizado sempre por homens, o pensamento seguirá normas e padrões mais ou menos idênticos e os produtores de pensamento se habituarão de tal forma que não serão capazes de acolher quando grupos diferentes, por exemplo, de mulheres, fizerem afirmações diferentes em relação a um mesmo conhecimento, porém de outra perspectiva e experiência corporal.

Na linha de Marcella Althaus-Reid (2000), toma-se consciência de forma especial da presença política da sexualidade na teologia, uma teologia política sexual, marcada por uma epistemologia que favorece conceituações de poder a partir do masculino, com marcas hegemônicas indiscutíveis nas crenças religiosas. Estas dão fundamento a manifestações culturais, sociais e políticas que mantêm hierarquias que excluem as mulheres, embora romantizem sua presença. Por essa razão, somos convidadas a ir mais longe do que a teologia da libertação, a tocar sua herança na teologia sistemática ou na dogmática tradicional das Igrejas cristãs. Este é o núcleo duro da questão, núcleo intocável pelos teólogos da libertação. Eles tocaram, por exemplo, a questão do Jesus histórico, mas era um personagem sem história de vivência sexual ou de seu estatuto real na vida da época. Era apresentado como um sujeito cujo foco era realizar a missão que Deus Pai Ihe entregara, ima- 
gem do foco dos próprios teólogos. Sem dúvida não havia dados nas Escrituras para teorizar sobre a dimensão relacional afetiva de Jesus, mas a forma como o apresentaram era mais a de um personagem com poderes especiais do que como um homem simples, carpinteiro de seu tempo, sobre o qual se escreveu e se inventou muitas coisas.

Ao falar da tensão com a sexualidade humana na teologia da libertação, quero referir-me também ao quase ocultamento das diversas formas de violência presentes nessa realidade humana e de maneira especial para com as suas vítimas. É como se a sexualidade não fosse algo integrante do conjunto da vida e fosse também marcada pela violência institucionalizada. Por isso a denúncia das mulheres feministas contra a consideração dessa realidade como periférica não foi aceita. Da mesma forma, os teólogos se sentiam incomodados com os acenos do feminismo à teologia da libertação e não viram com bons olhos a conversão de teólogas da libertação ao feminismo e suas bandeiras específicas de luta dentro da luta libertária social.

Entendem-se as razões pelas quais as teologias da libertação, sobretudo as da primeira geração, não abriram espaços reais para o feminismo, não o estudaram como novo desafio à ciência teológica e não expressaram os modos diferentes de fazer teologia a partir dos gêneros. Suspeito que essa falha continue a minar ainda as novas gerações de intelectuais que pretendem, dentro das igrejas, elaborar pensamentos libertários. Por isso, nossas certezas estão ameaçadas pela descoberta e vivência plural de nossas sexualidades complexas e desafiantes das ciências, das teologias, das crenças e das organizações sociais, políticas e religiosas, porém vitais para nossa existência. 


\section{A tensão com a antropologia feminista e outras antro- pologias}

Falar da tensão da teologia da libertação com a antropologia feminista pode parecer algo incompreensível e talvez até pretensioso (GEBARA, 2015), mas toda pretensão merece uma explicação.

O Cristianismo, da antiguidade até os nossos dias, mantém nos seus pilares antropológicos e filosóficos a supremacia da representação masculina e a redução das mulheres a auxiliares na história cristã. Esta supremacia, ainda que suavizada, manteve-se também na teologia da libertação.

A pretensão de uma mudança dos paradigmas androcêntricos vai delinear em grandes linhas o que se convencionou chamar de antropologia feminista. Entretanto, ela não é só para mulheres, mas trata de novas relações e de uma compreensão marcada pela horizontalidade e interdependência entre os seres humanos. Chama-se feminista porque vem sendo encabeçada por mulheres que aderem a um movimento social amplo de afirmação de direitos sociais e políticos, assim como uma compreensão igualitária e democrática dos seres humanos também no interior das religiões. Uma reflexão sobre o papel das mulheres na sociedade à luz de uma compreensão crítica de si mesmas está se fazendo também nas Igrejas e nas teologias. Uma libertação dos antigos padrões de comportamento está em processo crescente e tem sido afirmada como luta pela justiça. Tenta-se há mais de 40 anos modificar posturas políticas e morais, conteúdos teológicos, interpretações bíblicas que mantêm, ainda, a subordinação das mulheres nas Igrejas e na sociedade como base para a dominação masculina.

As leituras feministas da Bíblia e as críticas teológicas ao sistema patriarcal diante das dores e opressões dos corpos femininos levantaram inúmeras suspeitas em relação à maneira pretensamente universalista de tratamento dos corpos. Esse universalismo, mesmo que de forma mais mitigada, continuou presente nas expressões das teologias da libertação na suas referências ao reino de Deus, ao projeto de Deus, aos caminhos de Deus, ao 
seguimento de Jesus Cristo. Por isso, não bastou fazer "revolução teológica" a partir dos pobres e possibilitar o seu pluralismo dentro do mesmo discurso teológico bíblico que continuou branco, colonialista e masculino nos seus fundamentos. Sem dúvida, houve inclusões quanto ao objeto social e político da teologia, mas não quanto à estrutura mítica de sustentação da fé cristã. Nela, a base de nossa fé continua simbolicamente e poderosamente patriarcal e masculina. A ética social não conseguiu transformar a metafísica teológica. Portanto, é possível afirmar que não houve uma mudança antropológica substancial que propusesse outra antropologia teológica, outra dogmática; uma dogmática simbolicamente inclusiva e permeável ao diálogo entre as culturas e as diferentes identidades sexuais. Em outros termos, os dogmas do Cristianismo continuam com a mesma formulação androcêntrica, a autoridade da Bíblia quase a mesma e para os católicos, em especial, o Magistério da Igreja apenas masculino continua presente e atuante de forma centralizadora em relação às diferentes interpretações. Qualquer reflexão ou prática destoante é acusada de heresia e suscita violência por parte dos defensores de conteúdos e da linguagem tradicionais.

O Deus encontrado na Bíblia, diziam os teólogos da libertação, encontrava-se também nas relações de justiça a partir das análises sociais de classe. Por isso dele se afirmava: “Deus é encontrado no encontro com os homens, no compromisso com o devir histórico da humanidade" (GUTIERREZ, 1971, p. 238). Se é "encontrado" na justiça, é perdido também nas injustiças, talvez nos fracassos e na ignorância que vive e cresce em nós e em nosso meio. A imagem do Deus libertário se afirmava como o reverso do Deus da direita, cujo poder se manifesta numa ordem hierarquizada e pré-dada do mundo. Na mesma linha, se encontra no reverso do Deus das mulheres, vivido em forma de suspiros e clamores ocultados nas "insignificâncias" de seu cotidiano.

Antes, a imagem do Deus libertário parecia clara como expressão do desejo de libertação de muitos. Ser da teologia da libertação era acreditar num "modelo" específico de Deus, o Deus do Êxodo 
A Teologia da Libertação e as mulheres

que conduz a sociedade e a Igreja pelos caminhos da libertação, o Deus de Jesus Cristo libertador, crucificado pelos sistemas de opressão, mas ressuscitado pelo amor do Pai. O mesmo sucederia com os pobres. Era um modelo quase científico de libertação inspirado por Deus através da Bíblia, uma proposta pensada por um grupo, um pensamento elaborado a partir e para os pobres que se pretendeu diferente da cristandade moderna, embora tivesse guardado muitos de seus ranços. Afirmando a autonomia do mundo em relação à Igreja, essa teologia continuou institucionalmente julgando o mundo a partir de suas políticas religiosas. Continuou afirmando a necessidade de mudanças a partir da fé do povo pobre, que deveria ser artesão de sua própria história. Mas como se explicitava esta fé? E como se poderia viver isso em meio à penúria e pobreza do continente? Como mulheres pobres, vivendo múltiplas violências, poderiam aceder a ela? Movimentos sociais, alianças com movimentos libertários armados e utopias sociais pareciam garantir o futuro do advento do Reinado de Deus.

A Teologia da Libertação começa a enfraquecer-se no meio do povo ao mesmo tempo em que começou o enfraquecimento dos movimentos populares de esquerda. Durante muito tempo não tínhamos consciência dos enganos e limites de nossas análises. Acreditávamos na vitória de nosso processo, acompanhados por Jesus Cristo libertador, sem pensar que os Herodes continuavam também a sua política de fidelidade ao Império.

Podemos dizer que hoje há poucas novidades na teologia que acompanham a complexidade do momento. Poucos são os novos teólogos da libertação que introduzem reflexões a partir dos acontecimentos ${ }^{6}$ e da conjuntura atual de nosso mundo. Entretanto, para o espanto de alguns, gostaria de sublinhar o fato de que muitas dessas preocupações e críticas feministas, para além das fronteiras confessionais e nacionais, já estavam presentes no feminismo e nas teologias feministas norte-americanas, europeias e latino-americanas nas décadas de 1980, de 1990 e até antes. As

6 Menciono a interessante tese doutoral de Daniel de Souza intitulada "A revolta da ineficiência: os acontecimentos de Junho de 2013 no Brasil e suas destituições político-teológicas", defendida em abril de 2019 na Faculdade Metodista de São Bernardo do Campo - SP. 
reflexões de Mary Daly (1973) e outras eram, entretanto, ignoradas e as feministas criticadas como imperialistas.

Diante dessas reflexões, poderíamos talvez nos fazer perguntas mais diretas: o que seria uma antropologia feminista? Que desafios reais ela levantaria para uma teologia da libertação?

Uma antropologia feminista é nada mais do que uma antropologia sem pré-definições do humano na linha da ordem perfeita estabelecida pelo Deus patriarcal. Uma antropologia feminista parte das dores das pessoas para além das hierarquias de gênero, que classificam e condenam a partir de um modelo único de humanidade. Revela a história das mulheres na construção do mundo humano, construção esta ocultada e desvalorizada. É uma antropologia que desnuda as tramas do controle das hierarquias religiosas em cumplicidade com as hierarquias econômicas, políticas e sociais. Uma antropologia como um coral de vozes múltiplas, em que a harmonia expressa a fé que nos habita como acolhida do dom da vida na diversidade de formas e linguagens. Esse coral se expressa numa linguagem inclusiva e cuidadosa das questões que envolvem culturas, sexos e etnias, revelando uma atenção especial para as diferenças e convergências que nos caracterizam. Essa antropologia é chamada de feminista porque nós mulheres a apreendemos e divulgamos como nascida de nossas entranhas. Ela habita em nós, talvez de forma especial, na percepção da diversidade de interpretações do mundo que derruba os dualismos de seus tronos excludentes.

Ouso dizer que a vida plural dos seres humanos, para além dos argumentos de autoridade religiosa que ordenam tudo a partir de Deus, convida a reorganizar a Igreja em comunidades plurais, a retomar coletivamente novos sentidos e não colocar remendos nas roupas velhas. Esta parece ser uma direção evangélica fundamental, apesar das muitas dificuldades. Ouvir mais uns e outras. Acolher as necessidades coletivas dos corpos na sua diversidade. Entregar poderes e revisá-los coletivamente. Refletir, acrescentar, compreender e analisar em conjunto para que haja mudanças efetivas faz parte do ideário feminista para as igrejas. 
O que propomos pode ser um desvario intelectual, uma desordem, um sonho impossível, mas é também uma aposta para a construção de outra fraternidade, outra sororidade, outra comunidade, outro cristianismo nos quais não somos integrados pelas hierarquias elitistas, mas criadoras de nossos novos significados provisórios e de nossa simbologia. "Como se fará isso se não conheço homem?", diz Maria no Evangelho de Lucas. E o anjo responde: "O Espírito virá sobre ti". Acreditar que o Espírito, sopro renovador de vida está em nós e entre nós é o grande desafio e a urgente necessidade do momento. Não negamos as tradições passadas, mas queremos reinterpretá-las hoje para responder aos desafios do presente, diante dos quais queremos ter voz ativa. Penso que este é um desafio e alguns efeitos da antropologia feminista consciente de seus limites, mas consciente também de suas possibilidades de compreensão do novo momento dos seres humanos viventes do planeta azul.

\section{O desafio da ecologia e da nova história do universo}

Muitas mulheres e homens, intelectuais cristãos, têm constatado a pequenez do Deus cristão preocupado apenas com os animais humanos e suas brigas históricas. É claro que essa pequenez é compreensível no passado, mas no século XX, com a destruição do mundo natural, com os desastres atômicos e com as guerras, outro discurso se fazia necessário. A pergunta que precisa ser respondida é: qual o significado do mundo natural ou da natureza física ou do planeta para a teologia cristã?

Descobrimo-nos, hoje, como apenas um instante da evolução de nossa galáxia, recém-chegados na história da vida e com uma bagagem destrutiva pesada formada ao longo dos séculos. Descobrimo-nos dependentes de um mundo mais amplo que chamamos natureza e sem a qual seria impossível viver. É desse lugar maior que tiramos nosso alimento, nossa bebida, nossa respiração. E parece que quando falamos da "salvação" ou da "liber- 
tação" cristã, nos esquecemos de incluir esse lugar maior do qual somos apenas uma ínfima parte. Não incluímos o mundo natural como sagrado e anterior e maior do que nós e nossas crenças. Reafirmamos que Deus fez o homem e deu-lhe poderes para submeter tudo a ele. Mais uma vez a primazia do mundo hierárquico patriarcal dá prioridade à vida de alguns em detrimento da vida da maioria e em detrimento do mundo natural, hoje também misturado com o artificial.

Como a teologia da libertação viu a destruição de nossa Terra, nossa casa maior? Não é resposta fácil, pois estávamos imersos nas ditaduras militares, na miséria e nas muitas injustiças vividas pelo povo da América Latina. Por isso não se trata de um julgamento, mas de uma tensão significativa entre a adesão teológica a uma tradição patriarcal e um convite para repensar a herança cristã em moldes mais amplos e inclusivos do mundo natural.

Alguns teólogos da libertação como Leonardo Boff e Frei Betto, mais recentemente se abriram para a ciência ecológica e a astrofísica como mediações para a teologia da libertação (BOFF, 2015). Entretanto, essa abertura não significou uma mudança radical de paradigmas e estruturas do pensamento teológico tradicional. Com isso, estou afirmando que há uma percepção mais ou menos clara de que cada vez que nos abrimos para uma problemática nova na teologia cristã, especialmente a católica romana, podemos apenas incluí-la na grande lista de problemas humanos, mas não admitimos a revisão e reformulação da dogmática teológica. Agimos como se ela fosse um depósito elástico no qual os novos problemas se incluem, porém não modificamos a textura e a forma do recipiente. $O$ grande desafio é modificar a forma do recipiente, pois ele acaba dando a todas as novidades e desafios a forma antiga, como se ela fosse imutável e imortal. Sem dúvida há o risco da dissolução do depósito, mas o risco maior é o da explosão do planeta, da extinção de muitas espécies inclusive a humana, caso as ideologias religiosas, suas posses, palácios, poderes e privilégios, não mudem sua forma verticalista de ver o mundo. Nessa linha, podemos dizer que alguns teólogos e teólogas ensaiaram 
a mudança do "depósito elástico", porém chegaram a ser severamente criticados por seus pares visto que pareciam desviar a causa da libertação social para um paradigma considerado distante da injusta realidade cotidiana. Não se percebeu a necessidade de outra história quando a velha história da criação já não era mais significativa e performativa. O velho mito, de fato, formou por muitos séculos nossas emoções e convicções em relação às origens e à conservação do mundo. Através dele tínhamos certa ordem nas perguntas e respostas sobre nossas origens, muito embora nossos sofrimentos continuassem os mesmos na sua diversidade.

Um vazio significativo tomou conta de nós, um vazio que expressava a necessidade de outra história de nossas origens, outra compreensão da inter-relação de nossos corpos, afirmando-nos como corpo da terra e o divino mistério em tudo. Mas, introduzir essas novidades significava mais uma vez destronar velhos poderes e permitir o nascimento de dúvidas e turbulentas emoções.

A nova história do universo acompanhou a crítica a uma visão colonialista e patriarcal da Bíblia e da Tradição das Igrejas cristãs, assim como dos dogmas cristãos na sua formulação canônica. Não faltaram estudos nessa linha. Entretanto, a questão ecológica foi para muitos apenas um adendo, uma inclusão, uma incorporação no discurso libertário e talvez até incentivo em vista de algumas práticas sociais e ecológicas pontuais. Porém, não significou uma real mutação que sem desprezar as cosmovisões e mitos do passado, acrescentaria a elas a dimensão evolutiva do universo e de nossos conhecimentos e permitiria um tipo de leitura mais humilde de nossa Tradição - enxertada em um movimento mais amplo. Entretanto, uma contrapartida foi imediatamente sentida. O movimento na direção dos fundamentalismos religiosos restaurou com força o uso abusivo da Bíblia como palavra divina que cura e dá segurança aos fiéis. Além disso, proporcionou o desenvolvimento de moralismos e uma recusa de integrar os novos avanços da ciência física às perguntas teológicas de nossa tradição, apenas uma tradição entre outras. 
A Teologia da Libertação e as mulheres

Creio, de fato, que os processos de mudança são lentos, também para a geração que viveu com foco na centralidade das relações entre os humanos e Deus a partir das categorias analíticas de esquerda. Nesses processos, a Bíblia e até a tradição de alguns Padres da Igreja podiam entrar, mas não havia chance para as questões ecológicas, as da astrofísica, os feminismos e a maioria das conquistas científicas. Por isso, para muitos libertários a ecologia e particularmente a ecologia profunda, que se atrelava à ciência astrofísica e à teoria da evolução, significou um desvio das grandes questões da libertação. Sem perceber, talvez, continuavam a situar o ser humano no centro do universo ou no centro da História e muitos imaginavam que ao falar do processo evolutivo da vida e da morte da vida, das florestas, rios, mares e animais, era uma espécie de romantismo sem saídas políticas reais. Temos dificuldade de conectar os conteúdos teológicos que nos ensinaram e os reproduzimos como produtores também de formas indiretas de destruição da vida. Ao apontar o dedo acusador dos outros insaciáveis de poder e de dinheiro, não percebemos que nossas teorias teológicas Ihes dão sustento e indiretamente também são responsáveis pela destruição do mundo natural na medida em que permitem convergir todas as vidas do planeta para a dominação humana. Não podemos mais ignorar a interdependência nas relações sociais, nos conhecimentos e com todas as formas de vida. Ninguém é inocente dos crimes coletivos e individuais quando se trata do planeta.

Ouso afirmar que não se trata aqui primeiro de um problema religioso específico, mas de um problema de sustentação filosófica da teologia. De fato, o Cristianismo, a partir de sua estrutura antropocêntrica/androcêntrica, contribuiu para acentuar comportamentos parciais e limitativos das relações humanas com o chamado "mundo natural". Reafirmou-se através dos mitos creacionais" uma Terra voltada para o homem e sob o domínio do homem. Entretanto, quando aludimos à história do universo, ao chamado Big Bang, entramos numa referência mais ampla porque se trata da

7 Mitos creacionais são as construções de sentido não históricas factuais que explicitam a criação do mundo por Deus ou pelos deuses. O Livro do Gênesis, por exemplo, contém alguns deles. 
explosão criadora do universo, de um evento captado pela ciência, evento comum a toda nossa galáxia, ao planeta, aos seres vivos e aos seres humanos. As tradições religiosas na sua diversidade se enxertariam como momentos pontuais nessa história ampla e em contínua evolução no esforço de não reduzir o comum ao próprio e de não apropriar-se da totalidade dos sentidos. Essa acolhida da unicidade originária na diversidade de expansões poderia possibilitar formas de diálogo e respeito às diferentes reverberações da vida. Como ensina Thomas Berry, astrofísico católico, os diferentes mitos e tradições provêm de necessidades culturais e contextuais de diferentes povos. Nenhuma pode pretender a supremacia sobre as outras (BERRY, 1988).

Entretanto, nesse mesmo turbulento contexto, muitas mulheres teólogas feministas se debruçaram sobre os desafios da astrofísica e das tradições indígenas e africanas do continente. Criaram grupos no Chile, no Brasil, no Peru, no Equador e em outros lugares, assim como ensaios diferentes em teologia ecofeminista latino-americana (GEBARA, 1997). Não tiveram sucesso no mundo masculino da libertação, embora algum sucesso no mundo das mulheres. Hoje, sua força se vê diminuída pelas políticas nacionais e internacionais de contenção de gastos.

A necessidade de mudanças no pensar e atuar das Teologias e da organização das igrejas cristãs se impõe como um longo caminho que começou a ser percorrido, mas tem encontrado atropelos e entraves provindos de diferentes grupos e personalidades poderosas.

\section{A tensão das novas políticas e novas éticas}

Falar de novas políticas e novas éticas como um ponto de tensão para a teologia da libertação pode parecer uma questão anacrônica e mesmo descabida, visto que a ela se apresentou como uma ética teológica. Porém, cada tempo e cada grupo tenta 
responder aos desafios que a história Ihes lança e parece que isso a teologia da libertação em seu surgimento tentou realizar. Mas, a questão que levanto nessa tensão não é a crítica ou o julgamento ao passado a partir do presente, mas a de verificar que no passado e no presente as teologias que pretendem permanecer na ortodoxia não dão conta do pluralismo da sociedade e aquelas que pretendem abrir-se e ajustar-se às novas exigências encontram nas próprias instituições religiosas seus maiores opositores.

Além disso, uma metodologia de diálogo interdisciplinar, inter-religioso, interpartidário e inter-movimentos sociais que tome o sofrimento dos mais pobres, das mulheres, dos emigrantes e outros em conta está fazendo falta. Nos habituamos a defender sempre nosso ponto de vista como o verdadeiro e nossos interesses, mesmo que sejam direcionados, para os pobres. Esta postura é própria das convicções que tínhamos nos anos 70, 80, 90 e 2000, a partir das quais acreditávamos também na universalidade da teologia da libertação, considerada quase como um sinônimo da teologia. Em outros termos, se dizia que a verdadeira teologia é a teologia da libertação ou que uma teologia para ser teologia tem que ser da libertação. E isto porque o nome de Deus estava implicado na palavra teologia, ciência de Deus, e Ele só podia querer o bem de seu povo. De maneira imperceptível, reforçávamos os dualismos entre o bem e o mal, o nós e os outros e sempre queríamos converter os outros para o nosso lado. Diante dos impasses que a história tem nos apresentado, começamos a reconhecer os limites da metodologia dos bons ou dos inspirados por Deus. Estamos dando os primeiros passos para um diálogo que nos convida a ouvir os outros e as outras, a conhecer sua história e suas razões.

Na mesma linha, tomamos consciência de forma mais aguda que as doutrinas tradicionais e o modelo de autoridade estabelecido não dão conta dos problemas e das reivindicações desses novos tempos. Nessa linha, os parâmetros estabelecidos pelas teologias da libertação também não conseguem lidar com a mistura atual das necessidades e dos poderes; não alcançam compreender as reivindicações e a complexa vida psíquica das pessoas e particular- 
mente dos pobres. Os pobres, economicamente falando, são cada vez mais plurais e suas expectativas se aproximam das ofertas das sociedades de consumo e das crenças que os ajudam a serem consumidores.

As teologias da libertação nasceram em outro contexto, em outra explicitação do papel da Igreja, em outra referência às tradições, em outra leitura da História humana, em outra fase do capitalismo. Agora estamos em uma etapa diferente, com outros poderes, com outros desejos e outra vida psíquica e emocional. Por isso afirmo a tensão entre o que era e o que está sendo e a necessidade de uma autocrítica séria para não repetirmos algumas limitadas visões de ontem.

Como escreve Vladimir Safatle (2015, p. 194): “Não há poder que não crie uma 'vida psíquica' através das marcas que deixa nos corpos". Que marcas os novos poderes do liberalismo, as igrejas emergentes, a volta das políticas conservadoras têm imprimido nos corpos múltiplos habitados por desejos múltiplos? E que marcas os movimentos feministas, homossexuais, transexuais, de emigrantes, dos sem-teto, sem-terra têm revelado? Por consequência, a que necessidades corporais e espirituais as igrejas cristãs têm respondido no atual contexto de instabilidade social? Como se pode falar da libertação?

As novas práticas das mulheres e outros grupos têm revelado novas teorias teológicas ausentes das instituições e da dogmática tradicional ainda em vigor. O povo frequentador das igrejas parece longe dos conflitos religiosos e das muitas teorias em voga. Estão situados, presentes talvez num lugar preciso, o templo, envoltos num sentimento de busca de ajuda individual para seus muitos males. É isso que lhes interessa em primeiro lugar. Alheios ao que acontece nas instituições do "sagrado", nas contradições teóricas e práticas, nas insuficiências de racionalidade, comportam-se mecanicamente através das palavras de ordem para encontrar talvez um rumo de vida segura: "Sentem-se!", "levantem-se!", “ouçam!", "façam!", “cantem!", “louvem!", “aplaudam!"... “Deus quer", “Deus disse", "Deus mandou"... Pedem, fazem promessas, peregrinações 
incentivadas pelos líderes das igrejas e seus acólitos. Rituais belos, talvez distantes do cotidiano, introduzem uma espécie de magia, de parêntesis, de ritmo e de parada para garantir o próximo passo da vida. As teorias da religião e as crenças cotidianas são distantes de fato umas das outras. Provérbios, ditos populares, canções, pedaços de histórias bíblicas, orações consideradas fortes, novenas, rituais diversos, promessas, sacrifícios misturam-se aparentemente às elaborações teológicas oficiais. Tudo envolto em uma esperança mágica de que os céus ouvirão os clamores dos pobres e os muitos mediadores serão seus intercessores. Uma tênue esperança sustenta os fiéis conformados com a vontade de Deus sobre eles mesmos. Às vezes um pedido se realiza, porém milhares são remetidos ao "Deus não quis". Tudo isso é convite para repensar a Teologia e as práticas religiosas incentivadas por um clero ávido de poder e de ter.

As igrejas e as teologias acompanham a dança das diferentes sociedades e de suas políticas. A palavra "libertação" penetra em muitos discursos, mas parece mais uma prática do passado em que dar a vida pela liberdade e para a justiça era sinal de fidelidade a Deus e a Cristo. Estas justificações grandiosas, embora não percam o seu valor simbólico, hoje se expressam de outra maneira por meio de solidariedades efetivas entre pessoas e grupos que buscam manter a vida minimamente centrada no direito e na justiça.

\section{A tensão entre a institucionalidade e a não instituciona- lidade das teologias}

A Teologia da Libertação latino-americana foi um pensamento dentro da Instituição eclesial, para ela e a partir dela. Embora tenha sofrido críticas de muitas autoridades religiosas, especialmente no Pontificado de João Paulo II, continuou sendo um pensamento desenvolvido por membros esclarecidos e respeitados das Igrejas. Tal fato Ihe dá um poder particular e um reconhecimento 
por parte dos fiéis e de intelectuais acadêmicos não necessariamente cristãos. Nessa linha, se pode dizer que o fato de ter sido pensada por uma maioria de homens e clérigos lhe deu grande autoridade institucional. Dessa forma, conseguiu se expandir em alguns Seminários, Institutos de Formação, Faculdades de Teologia e encontrou espaços editoriais nacionais e internacionais.

As teólogas feministas da libertação, que no final dos anos 1970 começaram a organizar-se e desenvolver-se de forma original, não puderam contar com suas instituições religiosas de origem. Não tiveram espaços nas salas de aula das faculdades de teologia, não tiveram espaços nos púlpitos e nas pastorais, não tiveram espaços editoriais confessionais que lhes concedessem estímulo e que lhes publicassem obras incipientes. Muitas teólogas foram objetos de crítica e desrespeito. Foram combatidas, silenciadas e expulsas discretamente do trabalho que faziam em suas instituições de origem à medida que se afirmavam como feministas. Nesse contexto deplorável, organizaram-se fora dos muros institucionais criando uma diversidade de pequenas organizações voltadas à educação religiosa das mulheres, sobretudo de meio popular. Nem mesmo os teólogos da libertação entraram em sua defesa publicamente. Algumas poucas subsistiram em Universidades Católicas por algum tempo, como no Rio de Janeiro, porém sua atuação profissional teve que adequar-se às exigências da doutrina masculina. Nenhum passo em falso podia ser dado, especialmente quanto às questões da sexualidade humana e da natalidade, assim como nenhuma crítica à dogmática tradicional podia ser feita. Por essa razão, as teologias feministas na sua diversidade se desenvolveram "fora dos muros das igrejas". Ajudadas por instituições internacionais de financiamento, elas se organizaram em diferentes grupos nacionais e conseguiram influência significativa nos grupos de mulheres. Tiveram espaços em grupos feministas preocupados com as questões religiosas das mulheres pobres, assim como em algumas universidades internacionais que na década de 1990 abriram espaços para o feminismo latino-americano. 
A Teologia da Libertação e as mulheres

Algumas mulheres se reconheceram na Teologia da Libertação, sobretudo nos anos 1970 e 1980, porém nenhum teólogo da libertação se reconheceu como feminista (RESS, 2012). Ser feminista era e é de certa forma diminuir sua qualidade teológica masculina e, por isso, excluíram essa palavra de seu vocabulário e de seu horizonte de pensamento. Os mais avançados ainda ensaiavam a expressão "teologia feminina", porém não iam mais longe porque no fundo sentiam que a questão de gênero na teologia era uma usurpação de um direito segundo eles adquirido desde a "fundação do Cristianismo". A Teologia feminista só encontrou e encontra algum espaço institucional em algumas cidades como no México, DF, quando por deferência dos "donos" da instituição e com recursos próprios das mulheres se consegue organizar cursos e congressos de teologia feminista. Porém, deve ficar claro que esta não é a teologia da Instituição ${ }^{8}$ É apenas um pensamento diferente, tolerado, e não se hesita em cortar espaços quando alguma "teóloga da casa" ousa ensinar algo que destrua ou macule a tradição masculina.

A não institucionalidade da Teologia Feminista da Libertação é um fato com desdobramentos previsíveis e imprevisíveis, visto que os espaços e canais alternativos de reprodução desse pensamento têm sido cada vez menores. A onda conservadora e fundamentalista que tomou conta de boa parte do continente, incluindo muitas faculdades de teologia, tem acirrado os processos de resistência institucional ao feminismo e em consequência à presença das teólogas feministas.

Lembrar a questão da institucionalidade da produção da Teologia da Libertação e a não institucionalidade da teologia feminista é um desafio nesse mundo plural e nos convida a pensar criticamente sobre o futuro das teologias e seu lugar na evolução do mundo. Pensar o presente e o futuro à medida que somos desafiadas a escolher entre a institucionalidade oficial sufocante ou a insubordinação criativa em relação a um pensamento que não nos

8 Cátedra de Teologia Feminista, Universidad Iberoamericana, Ciudad de Mexico. 
A Teologia da Libertação e as mulheres

permite um desabrochar mais inclusivo e performativo da tradição cristã: o dilema segue na atualidade sem respostas definitivas.

\section{Conclusão: - Para onde estamos indo?}

As cinco tensões e enfrentamentos assinalados acima nos conduzem à percepção de que estes não são apenas teóricos desafiando apenas a teologia da libertação, estão na realidade presentes na vida do conjunto dos cristãos - embora nem sempre expressos de forma consciente, organizada e explicitada teoricamente. As problemáticas apresentadas estão na sua especificidade interligadas nas muitas relações entre os diferentes grupos humanos. Nesse sentido, a própria expressão "teologia da libertação" necessita ser reinterpretada uma vez que buscamos sua sobrevivência nos novos contextos sociais de nosso continente e na importância do protagonismo feminino. Seria talvez melhor falar de teologia de libertações porque a liberdade é um busca contínua que exige renovados esforços de educação para não nos sujeitarmos às nossas paixões internas e externas e a nossos velhos senhores.

Essas libertações acontecem como pequenos pontos luminosos no cotidiano das lutas de cada dia e nos permitem experimentar apenas breves libertações ou, para usar uma linguagem tradicional no cristianismo, algo da salvação esperada. Talvez esse provisório salvífico possa introduzir pequenas mudanças práticas e teóricas, debutar processos educacionais ou outras mudanças reais que escapam a nossas previsões. Talvez possam ajudar-nos a sermos agentes mais ativas de nossas vidas na responsabilidade de ajudar-nos a carregar os fardos uns dos outros no aqui e agora de nossa história.

A salvação é na história mesmo quando a queremos elevá-la acima dela. É na história e nas circunstâncias pessoais de cada uma que nos sentimos abandonadas, órfãs, carentes de mil e uma necessidades, sedentas de mil e um desejos insatisfeitos. A salvação 
é para os seres viventes, para os viventes do presente e do futuro, para os terrícolas na sua exuberante diversidade. É, pois, a partir do "planeta azul" que um segmento de seus viventes chamados humanos clama por salvação, estranhamente ora buscando-a só para si ora abraçando-se a toda a Terra no afã de extinguir dores e a sina da mortalidade que amedronta e dá calafrios.

As mulheres teólogas trazem essa salvação para terra e como outras tradições, inclusive a cristã, bendizem também a morte e suas marcas em seus frágeis corpos. Nessa linha, elas têm se esforçado para trazer ao cotidiano as pequenas libertações e as pálidas expressões do Mistério Maior que nos tece e sustenta. Tudo se passa no pequeno mundo de nossas conquistas de terra, de moradia, de direitos civis, de pequenos prazeres, de descobertas de nossa força, de expansão de nossos conhecimentos, de reconhecimento de nossa arte como sinais que apontam para a superação provisória dos sistemas que nos oprimem. Por isso também estamos falando de sororidade entre nós.

No marasmo de nosso tempo é no hoje que encontramos as breves certezas, os fugidios sentidos, os pequenos amores que se parecem ao fermento misturado à farinha, amassada e re-amassada até que se torne o pão nosso de cada dia. Amanhã, há que se recomeçar de novo como se repetíssemos a cada dia a aventura do sentido e da liberdade em nossas vidas. Reconhecemos nesses gestos repetitivos a vida continuando a nascer, morrer, ressuscitar a cada novo dia. Nessa linha poética fazer teologia feminista é acolher os sentidos entregues a cada dia, tentar entendê-los com velhos e novos meios, reproduzi-los ou transformá-los no ordinário da vida. É nesse pequeno e único cotidiano que encontramos os sentidos que dão sabor à vida, a força vital para seguir adiante, as mãos que seguram as nossas e não nos deixam cair na tentação do narcisismo, do orgulho cego, da bondade e da justiça impostas. Somos agora forças nacionais e internacionais atentas às violências múltiplas que nos atingem, prontas a ajudar umas às outras para além das várias fronteiras que nossos semelhantes masculinos construíram. 
- O que permanece hoje da teologia da libertação?

Permanece em primeiro lugar uma profunda gratidão pelo sonho renovado da libertação dos pobres, as memórias de compromissos assumidos que levaram muitos/as à morte violenta ou aos fétidos cárceres das ditaduras. Permanece a história dos que comungaram o amor ao próximo como fonte e sentido de suas vidas e acenaram de longe à "Terra prometida". Eles e elas ainda reavivam e nutrem nosso amor.

O que permanece hoje? Permanece a convicção de que a História humana não pode ser dominada pelas teorias sobre ela, que a fé de uns e outras pode mover montanhas de ódios inesperados e pode abrir esperanças tópicas e utópicas.

O que permanece hoje? Permanecem as "topias" concretas das mulheres que desde a madrugada estão nas filas das prisões para visitar filhos, maridos e amantes. As "topias" das mulheres em busca de seus direitos de igualdade salarial, de representação política e religiosa, de igualdade de espaços num mundo no qual deveríamos caber todas e todos.

O que permanece hoje? Permanece também uma sensação de insegurança, um sabor pouco definido na boca, um mal-estar difuso como se estivéssemos todas numa guerra ou errantes no deserto, ou ainda famintas por um pedaço de pão sem saber se seremos saciadas. Permanece finalmente e fortemente "as mãos dadas", o suficiente para acreditar que a solidariedade não morrerá e a dignidade comum poderá viver e reviver.

A fé, a esperança e o amor mútuo em doses diversas não nos abandonaram hoje e não nos abandonarão amanhã. Essa é uma verdade que a vida nos revela a cada dia, nela acreditamos e seguimos em frente. 
A Teologia da Libertação e as mulheres Ivone Gebara

\section{Referências}

ALTHAUS-REID, Marcela. La teologia indecente. Perversiones teológicas en sexo, género y política. Barcelona: Edicions bellaterra, 2000.

ARENDT, Hannah. The Human Condition. Chicago: The University of Chicago Press, 1958.

ARIÈS, Philippe ; BÉJIN, André (eds.). Western Sexuality: Practice and Precept in Past and Present Times. Oxford: Oxford University, 1985.

BERRY, Thomas. The dream of the earth. San Francisco: Sierra Club Books, 1988.

BOFF, Leonardo. Ecologia. Grito da terra, Grito dos pobres. Petrópolis: Vozes, 2015.

BUTLER, Judith. The psychic Life of Power. Stanford: Stanford University Press, 1997.

DAVIDSON, Arnold Ira. The Emergence of Sexualiry. Historical Epistemology and the Formation of Concepts. Harvard University Press, 2004.

DALY, Mary. Beyond God the father. Beacon Press, 1973.

DUSSEL, Enrique. Filosofia ética latino americana. México: Edicol, 1977.

GEBARA, Ivone. Teologia ecofeminista. Ensaio para repensar o conhecimento e a religião. São Paulo: Olho d'água , 1997.

GEBARA, Ivone. Longing for Running Water. Ecofeminism and Libertion. Minneapolis: Fortress Press, 1999.

GEBARA, Ivone. Le mal au féminin. Réflexions théologiques à partir du féminisme. Paris: L'Harmattan, 1999.

GEBARA, Ivone. Filosofia feminista. Montevideo: Doble Clic, 2015. 
GEBARA, Ivone. Mulheres, religião e Poder. São Paulo: Terceira Via, 2017.

GEBARA, Ivone; BINGEMER, Maria Clara. Maria Mãe de deus e Mãe dos Pobres. Coleção Teologia e Libertação. Petrópolis: Vozes, 1987.

GUTIERREZ, Gustavo. Teología de la Liberación. Lima: CEP, 1971. MCFAGUE, Sallie. The body of GOD. An ecological theology. Minneapolis, Fortress Press, 1993.

METZ, Jean-Baptiste. Teología Política. São Leopoldo: Editora EST, s/d.

PAPA FRANCISCO. Laudato Si. Vaticana: Librería Editrice Vaticana, 2015.

RESS, Mary Judith. Different Gods. Bloomington: Universe Books, 2018.

RESS, Mary Judith. Sin visiones nos perdemos. Reflexiones sobre Teología ecofeminista latinoamericana. Santiago, Chile: Colectivo Con-Spirando, 2012.

SAFATLE, Vladimir. O circuito dos afetos. São Paulo: Cosac Naify, 2015.

SOUZA, Daniel de. A revolta da ineficiência: os acontecimentos de Junho de 2013 no Brasil e suas destituições político-teológicas São Bernardo do Campo, 2019. Tese (Doutorado em Ciências da Religião). Universidade Metodista de São Bernardo do Campo, São Bernardo do Campo, 2019. 